\title{
11. ANHYDRITE IN HYDROTHERMALLY ALTERED BASALTS: DEEP SEA DRILLING PROJECT HOLE 504B, LEG 831
}

\author{
Jeffrey C. Alt, Eric S. Saltzman, and David A. Price, \\ Rosenstiel School of Marine and Atmospheric Science, University of Miami²
}

\begin{abstract}
Anhydrite occurs in veins in hydrothermally altered basalts recovered from Hole 504B during Leg 83 of the Deep Sea Drilling Project. Sulfur isotopic data indicate that the anhydrites formed from fluids with sulfur isotopic compositions similar to seawater sulfate. Anhydrite probably formed as a pulse of relatively unreacted seawater was heated when it entered a relatively hot hydrothermal system containing evolved fluids. Reheating and continued evolution of the system followed anhydrite deposition.

Preservation of anhydrite in Hole 504B was probably favored by the high temperatures and by the low permeability that resulted from the sealing of cracks with secondary minerals. Evidence also indicates that anhydrite was partly replaced by laumontite and prehnite at relatively high temperatures, and possibly by calcite at lower temperatures.
\end{abstract}

\section{INTRODUCTION}

Experimental studies of seawater-basalt interactions predict that anhydrite should form in submarine hydrothermal systems in quantities that may be significant in the exogenic cycle of sulfur (e.g., Bischoff and Dickson, 1975; see, also, summary in Mottl, 1983). However, only a few occurrences of anhydrite have been reported from the seafloor to date. Anhydrite has been identified from hydrothermal deposits on the seafloor at $21^{\circ} \mathrm{N}$ on the East Pacific Rise (Haymon and Kastner, 1981; Styrt et al., 1981). Sulfur and strontium isotopic data suggest that this anhydrite formed by heating of seawater and mixing of seawater with hydrothermal fluids (Albarede et al., 1981; Styrt et al., 1981; Vidal and Clauer, 1981; Kausakabe et al., 1982). Anhydrite also occurs in sediments in the Guaymas Basin, where it formed from seawater-derived fluids in which some prior sulfate reduction had occurred (Shanks and Niemitz, 1982). Drever et al. (1979) reported small amounts of gypsum and halite in a vein in basalts from DSDP Leg 45 and suggested that the gypsum formed by hydration of anhydrite that had formed at higher temperature. Despite these few occurrences of sulfates from the seafloor, anhydrite has been conspicuous by its general absence in drilled and dredged seafloor basalts, suggesting that anhydrite may be deposited in the rocks, but later removed through dissolution by cold seawater or reduction to sulfide.

Earlier, we reported the occurrence of anhydrite from the upper part of Hole 504B (Leg 70; Alt et al., 1983). The sulfur isotopic composition of those samples indicated extensive interaction of the fluids with the host rock prior to the precipitation of the anhydrites. Anhy-

\footnotetext{
${ }^{1}$ Anderson, R. N., Honnorez, J., Becker, K., et al., Init. Repts. DSDP, 83: Washington (U.S. Govt. Printing Office).

2 Addresses: (Alt, present address) Dept. of Earth and Planetary Sciences, Washington University in St. Louis, Campus Box 1169, St. Louis, MO 63130; (Saltzman, Price) Department of Marine Geology and Geophysics, Rosenstiel School of Marine and Atmospheric Science, University of Miami, 4600 Rickenbacker Causeway, Miami, FL 33149.
}

drite also occurs in basalts recovered during Leg 83, which extended Hole 504B to $1350 \mathrm{~m}$ below the seafloor and recovered basalts containing greenschist and zeolite facies mineral parageneses. In this chapter we present petrographic and sulfur isotopic evidence for the occurrence and origin of the Leg 83 anhydrites.

\section{HOLE 504B AND ALTERATION OF LEG 83 BASALTS}

Hole 504B is located in 5.9 m.y.-old crust south of the Costa Rica Rift in the eastern Pacific. The hole was drilled previously on Legs 69 and 70, when $274.5 \mathrm{~m}$ of sediment and $561.5 \mathrm{~m}$ of pillows, massive basalts, and breccias, altered at low temperatures (less than about $100^{\circ} \mathrm{C}$; Honnorez et al., 1983), were penetrated. On Leg 83 , Hole 504B penetrated $10 \mathrm{~m}$ of pillow basalts (836$846 \mathrm{~m}$ below seafloor); a 209-m transition zone (846$1055 \mathrm{~m}$ ) comprising pillows, massive basalts, and intrusive dikes; and $295 \mathrm{~m}$ of dikes and massive basalts (1055$1350 \mathrm{~m}$ ), interpreted to be part of a sheeted dike complex. Measured heat flow at the site falls close to the theoretical conductive cooling curve for oceanic crust, and temperatures in the hole fall on a conductive gradient, ranging from $60^{\circ} \mathrm{C}$ at the basement/sediment interface to $160^{\circ} \mathrm{C}$ at the bottom of the hole (Becker et al., this volume).

A detailed description of alteration of Leg 83 basalts is given in Alt et al. (this volume) and is briefly summarized here. From 836 to $898 \mathrm{~m}$ the basalts are uniformly dark gray and appear little altered in hand specimen. However, in thin section olivine is replaced by clay minerals and titanomagnetite is partly replaced by sphene. Veins are filled with clay minerals and small amounts of pyrite with calcite and anhydrite occasionally at the centers. Clay minerals both in rocks and veins consist of smectite with minor chlorite layers. Temperatures of alteration were probably greater than about $100^{\circ} \mathrm{C}$. The general sequence of secondary mineral deposition is (1) clay minerals followed by (2) calcite and anhydrite. 
From 898 to $1350 \mathrm{~m}$ the basalts contain superimposed greenschist- and zeolite-facies mineral parageneses. Olivine is replaced by clay minerals, plagioclase is partly replaced by albite and calcic zeolites, clinopyroxene is partly replaced by actinolite and minor magnetite, and titanomagnetite is extensively replaced by sphene. Clay minerals consist generally of chlorite, frequently with variable amounts of expandable layers (smectite and vermiculite), and talc also occurs locally. Clay minerals, quartz, epidote, sulfides, and, locally, prehnite are common in veins. Three stages of alteration have been identified in basalts from 898 to $1350 \mathrm{~m}$ based on cross-cutting relationships of veins, fluid inclusion, and chemical, oxygen, and carbon isotopic data on secondary minerals (Alt et al., Honnorez et al., both this volume). (1) Chlorite, actinolite, albite, sphene, pyrite, and minor quartz formed in veins and host basalts by reaction of the rocks with partly reacted seawater (Mg-bearing, locally metaland Si- enriched) at temperatures of at least $200-250^{\circ} \mathrm{C}$. This was followed by (2) formation of quartz, epidote, and sulfides in veins from relatively evolved (Mg-depleted, metal-, $\mathrm{Si}$, and ${ }^{18} \mathrm{O}$-enriched) seawater-derived fluids at temperatures of up to $380^{\circ} \mathrm{C}$, and, finally (3) zeolites, calcite, and prehnite formed from evolved fluids (Mg-depleted, Ca- and ${ }^{18} \mathrm{O}$-enriched, possibly with higher $\mathrm{pH}$ ) at temperatures of about $90-250^{\circ} \mathrm{C}$.

\section{ANHYDRITE IN LEG 83 BASALTS}

Anhydrite was identified optically and confirmed by $\mathrm{X}$-ray diffraction in eight samples from the Leg $83 \mathrm{sec}-$ tion of Hole 504B. The occurrence of anhydrite in the Leg 83 section is restricted to three zones: it occurs in minor amounts in veins from 846 to $862 \mathrm{~m}$ in the transition zone, as veins in basalt fragments over a $36-\mathrm{cm}$ in- terval at $1213.6 \mathrm{~m}$ in the dike section; and in veins, up to $1 \mathrm{~cm}$ wide, at the bottom of the dike section (1336.8$1346.2 \mathrm{~m}$ ). Descriptions of individual samples from this study are given in Table 1 . Anhydrite is less abundant than originally thought on board the Glomar Challeng$e r$, where it was confused with laumontite, which has a similar habit in hand specimen.

Anhydrite formed relatively late in the secondary mineral paragenetic sequence, during the third alteration stage, and is generally associated with zeolites and calcite. In most samples the relationship among these minerals is unclear or could not be observed, but in Sample 504B-141-1, 58-61 cm anhydrite is cut by and partly replaced by laumontite, and both phases are partly replaced by later prehnite (Plate 1, Figs. 3 and 4; Table 1). In Sample 504B-73-1, 45-49 cm laumontite occurs between laths of anhydrite, suggesting that anhydrite formed first (Alt et al., this volume). Thus, at least in these two samples, anhydrite formation preceded laumontite formation. However, in Sample 504B-73-2, 29-32 cm anhydrite appears to be intergrown with calcite (Table 1 ), suggesting that the two minerals may have formed at the same time.

\section{TECHNIQUE}

Anhydrites were separated by crushing veins and hand picking under a binocular microscope. Five anhydrite samples were dissolved in $1 \mathrm{~N} \mathrm{HC1}$, then filtered and brought to $\mathrm{pH} 2$ with $\mathrm{NaOH}$. The solutions were heated, and a few milliliters of $10 \% \mathrm{BaCl}_{2}$ solution were added to precipitate $\mathrm{BaSO}_{4}$. The precipitates were converted to $\mathrm{SO}_{2}$ by thermal decomposition (Bailey and Smith, 1972) and analyzed on a Micromass 602 ratio mass spectrometer. The accuracy of the measurements is approximately $\pm 0.15 \%$.

Results are reported in Table 1 as $\delta^{34} \mathrm{~S}$ relative to Cañon Diablo Troilite (CDT) using laboratory standards. The OGS and SL-277-6 (McMaster University) standards gave values of +20.3 and $+22.0 \%$, re-

Table 1. Sulfur isotopic data and description of anhydrite samples in Hole 504B basalts.

\begin{tabular}{|c|c|c|c|c|}
\hline $\begin{array}{l}\text { Core-Section } \\
\text { (interval in } \mathrm{cm} \text { ) }\end{array}$ & $\begin{array}{l}\text { Depth } \\
\text { (m BSE) }\end{array}$ & $\delta^{34} \mathrm{~S}\left(\% \%_{0} \mathrm{CDT}\right)^{\mathrm{b}}$ & Description & Host rock \\
\hline $40-3,130-135^{a}$ & 584 & +18.9 & $\begin{array}{l}\text { Anhydrite with calcite in } \mathrm{cm} \text {-sized vug lined with saponite. Doleritic host rock contains reddish } \\
\text { oxidation halo with ferric oxides replacing primary sulfides and olivine. }\end{array}$ & \multirow{2}{*}{$\begin{array}{l}\text { Contains } \\
\text { smectite }\end{array}$} \\
\hline $48-3,14-18^{a}$ & 650 & +36.7 & $\begin{array}{l}\text { Anhydrite prisms, up to } 5 \mathrm{~mm} \text { long, are intergrown with gyrolite at the center of a } 5 \text {-mm-wide vein } \\
\text { rimmed by saponite and quartz in a dark gray host rock. }\end{array}$ & \\
\hline $72-2,126-129$ & 846.3 & - & $\begin{array}{l}\text { Radiating laths of anhydrite, up to a few } \mathrm{mm} \text { long, at the center of a clay mineral vein in a dark } \\
\text { gray host rock. }\end{array}$ & \multirow{4}{*}{$\begin{array}{l}\text { Contains } \\
\text { sphene }+ \\
\text { smectite with } \\
\text { minor chlorite } \\
\text { layers }\end{array}$} \\
\hline $72-3,142-144$ & 847.9 & +21.9 & $\begin{array}{l}\text { Euhedral laths of anhydrite, up to } 0.45 \times 1.0 \mathrm{~mm} \text {, at the center of a clay mineral vein in a dark } \\
\text { gray fine-grained host rock. }\end{array}$ & \\
\hline $73-2,29-32$ & 854.3 & - & $\begin{array}{l}\text { Euhedral laths of anhydrite, up to } 0.8 \times 3.0 \mathrm{~mm} \text {, occur in radial aggregates, sometimes with } \\
\text { sparry calcite between the laths and both intergrown with clays at the center of a } 1-\mathrm{cm} \text {-wide } \\
\text { clay mineral vein in a dark gray host rock. }\end{array}$ & \\
\hline $74-1,46-49$ & 862.0 & +21.4 & $\begin{array}{l}\text { Anhydrite laths, up to } 0.3 \times 1.5 \mathrm{~mm} \text {, at the center of a vein comprised of clay minerals, pyrite, } \\
\text { and rimmed by quartz, in a light to dark gray, fine-grained host rock. See Plate } 1 \text {, Figs. } 1 \text { and } \\
2 \text {. }\end{array}$ & \\
\hline $122-1,4-27$ & 1213.6 & +21.5 & $\begin{array}{l}\text { Anhydrite laths at the centers of veins of chlorite with minor smectite layers, in light greenish, } \\
\text { fine-grained host rock. }\end{array}$ & \multirow{4}{*}{$\begin{array}{l}\text { Contains } \\
\text { greenschist } \\
\text { and zeolite } \\
\text { facies minera- } \\
\text { logies }\end{array}$} \\
\hline $139-1,29-33$ & 1336.8 & - & $\begin{array}{l}\text { Anhydrite and laumontite in mm-sized vein. Coarse-grained light greenish host basalt is extensively } \\
\text { recrystallized. Anhydrite was not observed in thin section of this sample, so the relationship of } \\
\text { the two minerals is unknown. }\end{array}$ & \\
\hline $141-1,58-61$ & 1346.1 & +21.3 & $\begin{array}{l}\text { Euhedral laths of anhydrite, up to } 1 \times 5 \mathrm{~mm} \text {, in } 1 \text {-cm-wide vein with chlorite, epidote, laumonti- } \\
\text { te, and prehnite, in light greenish host basalt that has been totally recrystallized to chlorite, } \\
\text { albite, actinolite, and sphene. Anhydrite is partly replaced by laumonite, and both phases are } \\
\text { partly replaced by prehnite. See Plate } 1 \text {, Figs. } 3 \text { and } 4 \text {. }\end{array}$ & \\
\hline $141-1,64-66$ & 1346.2 & +21.2 & $\begin{array}{l}\text { Anhydrite in veins and coating fractures on extensively altered light greenish basalt fragments. } \\
\text { Chlorite preceded anhydrite deposition on exposed fracture surfaces. }\end{array}$ & \\
\hline
\end{tabular}

\footnotetext{
a Data from Leg 70 (Alt et al., 1983). All other data from Leg 83, this chapter.

b Dashes indicate samples not analyzed for sulfur isotopes.
} 
spectively. Values reported by other laboratories for these standards are OGS: +20.05\% (Halas et al., 1979/1980); SL-277-6: + 21.7\% (Halas et al., 1979/1980), $+22.4 \%$, and $+23.01 \% 0$ (analyzed as $\mathrm{SO}_{2}$ and $\mathrm{SF}_{6}$, respectively; Rees, 1978).

\section{RESULTS AND DISCUSSION}

The $\delta^{34} \mathrm{~S}$ values of Leg 83 anhydrites range from +21.2 to $+21.9 \%$ (see Table 1 ). These values are consistent with precipitation from a fluid with a sulfur isotopic composition of seawater (20-21\%0; Rees et al., 1978). The slight enrichment of the anhydrite in $\delta^{34} \mathrm{~S}$ relative to seawater may be caused by a number of factors: fractionation during precipitation (Thode and Monster, 1965); small variations in the $\delta^{34} \mathrm{~S}$ of seawater during the last 6 m.y. (Claypool et al., 1980); or a small amount (about 5\%) of sulfate reduction in the fluid prior to anhydrite precipitation.

\section{Anhydrite Formation}

In two Leg 83 samples the formation of anhydrite appears to have preceded that of calcite and zeolites, whereas in another sample calcite and anhydrite may have formed at the same time. Oxygen isotopic and fluid inclusion data on calcite and zeolites, which formed most closely associated in time with anhydrite, indicate that they formed at temperatures ranging from 90 to $250^{\circ} \mathrm{C}$, and from fluids slightly enriched in ${ }^{18} \mathrm{O}$ (about $+1 \% 0$ SMOW; Alt et al., Honnorez et al., both this volume). Calcites also contain no detectable $\mathrm{Mg}$, are occasionally $\mathrm{Mn}$-rich, and have negative $\delta^{13} \mathrm{C}$ values, suggesting a magmatic carbon component (Alt et al.; Honnorez et al., this volume). The isotopic and chemical compositions of the calcites suggest that they formed from "evolved" seawater-derived fluids that were depleted in $\mathrm{Mg}$ and enriched in ${ }^{18} \mathrm{O}$ through reaction with basalts at high temperatures $\left(\geq 250^{\circ} \mathrm{C}\right)$. In experimental seawaterbasalt reactions similar "evolved" fluids depleted in $\mathrm{Mg}$ contain little or no sulfate (Seyfried and Bischoff, 1979, 1981; Seyfried and Mottl, 1982). By analogy with the experiments, the relatively reacted nature of the hydrothermal fluids during calcite and zeolite formation suggests that the fluids contained very little sulfate. It is possible that the anhydrite in Leg 83 basalts formed from the probably small amounts of residual sulfate in these "evolved" solutions. However, at temperatures greater than about $200^{\circ} \mathrm{C}$ inorganic reduction of sulfate can become important (e.g., Shanks et al., 1981; Ohmoto and Lasaga, 1982), and such evolved fluids might be expected to have undergone significant sulfate reduction. In contrast, the isotopic compositions of the Leg 83 anhydrites indicate very little or no sulfate reduction, suggesting that the anhydrite may not have formed from the same fluids as the calcites. This interpretation is consistent with the formation of anhydrite prior to that of calcite and zeolites.

This suggests that the anhydrites may have formed simply by heating of relatively unmodified seawater whose sulfur isotopic composition had not been altered by interaction with the basalts. Since circulating fluids prior to anhydrite formation were also relatively reacted seawater-derived solutions (see later), the crust penetrated by Hole 504B may have functioned as a recharge area for a hydrothermal system during the episode of anhydrite formation.

The relatively minor amounts of anhydrite in Leg 83 basalts suggest that large volumes of seawater were not entering the system during anhydrite formation. Fractures in the basalts recovered from the hole appear to have been mostly sealed with secondary minerals by the time that anhydrite formed; this may have restricted seawater ingress and anhydrite formation. New cracks did open, however, and were filled with zeolites and calcite (Alt et al., Honnorez et al., both this volume). Anhydrite is most abundant at the bottom of the dike section, where large veins occur in highly fractured and extensively altered host rocks. This suggests that seawater may have preferentially entered the crust along localized highly permeable zones. However, recovery of basalts drilled during Leg 83 averaged only about $15 \%$, so anhydrite could actually be more abundant in the crust at Site 504 than is indicated by the recovered cores.

The formation of laumontite following anhydrite in two samples and the replacement of both phases by prehnite indicates that the system did not permanently switch from a high-temperature hydrothermal zone to a recharge area. Rather, a pulse of relatively unevolved seawater into the system resulted in the formation of anhydrite, followed by continued evolution of the system, leading to formation of zeolites, calcite, and prehnite.

We do not wish to imply that sulfate reduction did not occur in the hydrothermal system, only that sulfate reduction did not significantly influence the isotopic composition of anhydrite in Leg 83 basalts. Pyrites in the Hole 504B sulfide-rich stockwork-like zone (910-928 m) have $\delta^{34} \mathrm{~S}$ values ranging from +2.9 to $+5.0 \%$ (CDT), indicating that some reduction of seawater sulfate did occur (Honnorez et al., this volume). However, the sulfides in the stockwork-like zone formed during the second alteration stage, before anhydrite formed, so the fluids that precipitated anhydrite in the core most likely were not involved in sulfide formation in the Hole 504B stockwork-like zone. There is also no evidence for any post-anhydrite sulfide formation in samples recovered from the hole. However, this does not preclude such an event: after anhydrite formed, sulfate left in solution could have been reduced and precipitated as sulfide elsewhere in the crust.

Sulfur isotopic data on anhydrites from Leg 83 basalts indicate little or no reduction of sulfate prior to anhydrite formation. In contrast, evidence for more extensive alteration of the sulfur isotopic composition of hydrothermal fluids was found in two anhydrite samples from the Leg 70 pillow section (Alt et al., 1983). One sample had a $\delta^{34} \mathrm{~S}$ value of $+18.9 \%$, suggesting formation from a mixture of basaltic and seawater sulfur, whereas the other had a $\delta^{34} \mathrm{~S}$ value of $+36.7 \%$ and is interpreted to have formed from seawater-derived fluids that were enriched in ${ }^{34} \mathrm{~S}$ through reduction of seawater sulfate. The variation in sulfur isotopic compositions among these and the Leg 83 samples point out that the sulfur in anhydrites is not always derived by simple heating and precipitation of seawater sulfate. 


\section{Anhydrite Preservation}

The presence of anhydrite in altered basalts from the Leg 70 and 83 sections of Hole 504B has answered the question of whether or not anhydrite forms in basalts in submarine hydrothermal systems; however, the question of how much anhydrite forms in the crust still remains. The low recovery from Hole 504B, where conditions for preservation of anhydrite were favorable, makes quantification uncertain.

There is no evidence to indicate that temperatures in the Leg 83 transition zone and dike sections were ever below about $100^{\circ} \mathrm{C}$ (Alt et al., Honnorez et al., both this volume), suggesting that the relatively high temperatures in this part of the hole favored the preservation of anhydrite. However, anhydrite is partly replaced by laumontite and prehnite in the lowermost samples from the hole where measured temperatures are the highest, suggesting that high temperatures may have promoted replacement of anhydrite. The fate of the sulfate released by anhydrite replacement is unknown.

In the Leg 70 pillow section, in contrast to the Leg 83 section, oxygen isotopic data on calcites indicate that temperatures probably ranged to as low as a few tens of degrees Celsius (Alt et al., this volume). Thus, some anhydrite may have been lost through dissolution by cold seawater. Lathlike calcite occurs in a vein in one sample from the Leg 70 pillow section of the hole (J.C.A., personal observation), possible as a pseudomorph after anhydrite, indicating that anhydrite may also be replaced by low-temperature phases. In the pillow section anhydrite formed late in the secondary mineral paragenetic sequence when cracks were mostly filled with alteration products. Combined with chemical evidence (Barrett, 1983; Barrett and Friedrichsen, 1983; Honnorez et al., 1983), this suggests that circulation of cold seawater following anhydrite formation was restricted, especially in the lower part of the pillow section, which probably favored preservation of anhydrite.

\section{CONCLUSIONS}

Anhydrite in Leg 83 basalts formed from fluids with sulfur isotopic compositions similar to that of seawater. Anhydrite probably formed as a pulse of relatively unreacted seawater was heated when it entered a relatively hot hydrothermal system containing evolved fluids. Reheating and continued evolution of the system followed anhydrite deposition.

Preservation of anhydrite in Hole 504B was probably favored by the high temperatures and by the low permeability due to sealing of cracks with secondary minerals. Petrographic evidence also indicates that anhydrite was partly replaced by laumontite and prehnite at relatively high temperatures, and possibly by calcite at lower temperatures.

\section{ACKNOWLEDGMENTS}

J.C.A.'s contribution was supported by NSF Grant OCE 81-17698 to J. Honnorez, whom J.C.A. thanks for his support and for the many helpful comments and discussions. E.S.S. thanks A. Castellanos for his assistance in the lab and acknowledges the support of Petroleum Research Fund Grant 1348AC2. The authors also thank W. E. Sey- fried and W. C. Shanks for reviewing the manuscript. Contribution from the Rosenstiel School of Marine and Atmospheric Science, University of Miami.

\section{REFERENCES}

Albarede, F., Michard, A., Minster, J. F., and Michard, G., 1981. ${ }^{87} \mathrm{Sr} /$ ${ }^{86} \mathrm{Sr}$ ratios in hydrothermal waters and deposits from the East $\mathrm{Pa}$ cific Rise at $21^{\circ} \mathrm{N}$. Earth Planet, Sci. Lett., 55:229-236.

Alt, J. C., Honnorez, J., Hubberten, H.-W., and Saltzman, E., 1983. Occurrence and origin of anhydrite from Deep Sea Drilling Project Leg 70, Hole 504B, Costa Rica Rift. In Cann, J. R., Langseth, M. G., Honnorez, J., Von Herzen, R. P., White, S. M., et al., Init. Repts. DSDP, 69: Washington (U.S. Govt. Printing Office), 547-550.

Bailey, S. A., and Smith, J. W., 1972. Improved method for the preparation of sulfur dioxide from barium sulfate for isotope ratio studies. Anal. Chem., 44:1542-1543.

Barrett, T. J., 1983. Strontium- and lead-isotope composition of some basalts from Deep Sea Drilling Project Hole 504B, Costa Rica Rift, Legs 69 and 70. In Cann, J. R., Langseth, M. G., Honnorez, J., Von Herzen, R. P., and White, S. M., et al., Init. Repts. DSDP, 69: Washington (U.S. Govt. Printing Office), 643-650.

Barrett, T. J., and Friedrichsen, H., 1983. Oxygen- and hydrogen-isotope composition of some basalts from Deep Sea Drilling Project Hole 504B, Costa Rica Rift, Legs 69 and 70. In Cann, J. R., Langseth, M. G., Honnorez, J., Von Herzen, R. P., White, S. M., et al., Init. Repts. DSDP, 69: Washington (U.S. Govt. Printing Office), 637-642.

Bischoff, J. L., and Dickson, F. W., 1975. Seawater-basalt interaction at $200^{\circ} \mathrm{C}$ and 500 bars: Implications for origin of sea-floor heavy metal deposits and regulation of seawater chemistry. Earth Planet. Sci. Lett., 25:385-397.

Claypool, G. E., Holser, W. T., Kaplan, I. C., Sakai, H., and Zak, I., 1980. The age curves of sulfur and oxygen isotopes in marine sulfate. Chem. Geol., 28:199-260.

Drever, J. I., Lawrence, J. R., and Antweiler, R. C., 1979. Gypsum and halite from the Mid-Atlantic Ridge. Earth Planet. Sci. Lett., 42: 98-102.

Halas, S., Lis, J., Szaran, J., and Trembaczowske, A., 1979/1980. A comparison of sulfur isotope standards used in different laboratories. Ann. Univ. Marine Curie-Sklodowska, Sect. AAA, 34-35 (5): $37-43$.

Haymon, R. M., and Kastner, M., 1981. Hot spring deposits on the East Pacific Rise at $21^{\circ} \mathrm{N}$ : Preliminary description of mineralogy and genesis. Earth Planet. Sci. Lett., 53:363-381.

Honnorez, J., Laverne, C., Hubberten, H.-W., Emmermann, R., and Muehlenbachs, K., 1983. Alteration processes in Layer 2 basalts from Deep Sea Drilling Project Hole 504B, Costa Rica Rift. In Cann, J. R., Langseth, M. G., Honnorez, J., Von Herzen, R. P. and White, S. M., et al., Init. Repts. DSDP, 69: Washington (U.S. Govt. Printing Office), 509-546.

Kusakabe, M., Chiba, H., and Ohmoto, H., 1982. Stable isotopes and fluid inclusion study of anhydrite from the East Pacific Rise at $21^{\circ}$ N. Geochem. J., 16:89-95.

Mottl, M. J., 1983. Metabasalts, axial hot springs, and the structure of hydrothermal systems at mid-ocean ridges. Geol. Soc. Am. Bull., 94:161-180.

Ohmoto, H., and Lasaga, A. C., 1982. Kinetics of reactions between aqueous sulfates and sulfides in hydrothermal systems. Geochim. Cosmochim. Acta, 46:1727-1745.

Rees, C. E., 1978. Sulphur isotope measurements using $\mathrm{SO}_{2}$ and $\mathrm{SF}_{6}$. Geochim. Cosmochim. Acta, 42:383-389.

Rees, C. E., Jenkins, W. J., and Monster, J., 1978. The sulphur isotopic composition of ocean water sulphate. Geochim. Cosmochim. Acta, 42:377-382.

Seyfried, W. E., and Bischoff, J. L., 1979. Low temperature basalt alteration by seawater: An experimental study at $70^{\circ} \mathrm{C}$ and $150^{\circ} \mathrm{C}$. Geochim. Cosmochim. Acta, 43:1937-1947.

1981. Experimental seawater-basalt interaction at $300^{\circ} \mathrm{C}, 500$ bars, chemical exchange, secondary mineral formation, and implications for the transport of heavy metals. Geochim. Cosmochim. Acta, 45:135-147.

Seyfried, W. J., and Mottl, M. J., 1982. Hydrothermal alteration of basalt by seawater under seawater-dominated conditions. Geochim. Cosmochim. Acta, 46:985-1002. 
Shanks, W. C., Bischoff, J. L., and Rosenbauer, R. J., 1981. Seawater sulfate reduction and sulfur isotope fractionation in basaltic systems: Interaction of seawater with fayalite and magnetite at 200 $350^{\circ} \mathrm{C}$. Geochim. Cosmochim. Acta, 45:1977-1995.

Shanks, W. C., and Niemitz, J., 1982. Sulfur isotope studies of hydrothermal anhydrite and pyrite, Deep Sea Drilling Project Leg 64, Guaymas Basin, Gulf of California. In Curray, J. R., Moore, D. G., et al., Init. Repts. DSDP, 64, Pt. 2: Washington (U.S. Govt. Printing Office), 1137-1142.

Styrt, M. M., Brackmann, A. J., Holland, H. D., Clark, B. C., Pisutha-Arnold, U., Eldridge, C. S., and Ohmoto, H., 1981. The mineralogy and isotopic composition of sulfur in hydrothermal sul- fide/sulfate deposits on the East Pacific Rise, $21^{\circ} \mathrm{N}$ latitude. Earth Planet. Sci. Lett., 53:382-390.

Thode, H. G., and Monster, J., 1965. Sulfur isotope geochemistry of petroleum, evaporites and ancient seas. Am. Assoc. Petrol. Geol. Mem., 4:367-377.

Vidal, P., and Clauer, N., 1981. Pb and $\mathrm{Sr}$ isotopic systematics of some basalts and sulfides from the East Pacific Rise at $21^{\circ} \mathrm{N}$ (Project RITA). Earth Planet. Sci. Lett., 55:237-246.

Date of Initial Receipt: 29 June 1983 Date of Acceptance: 12 December 1983 

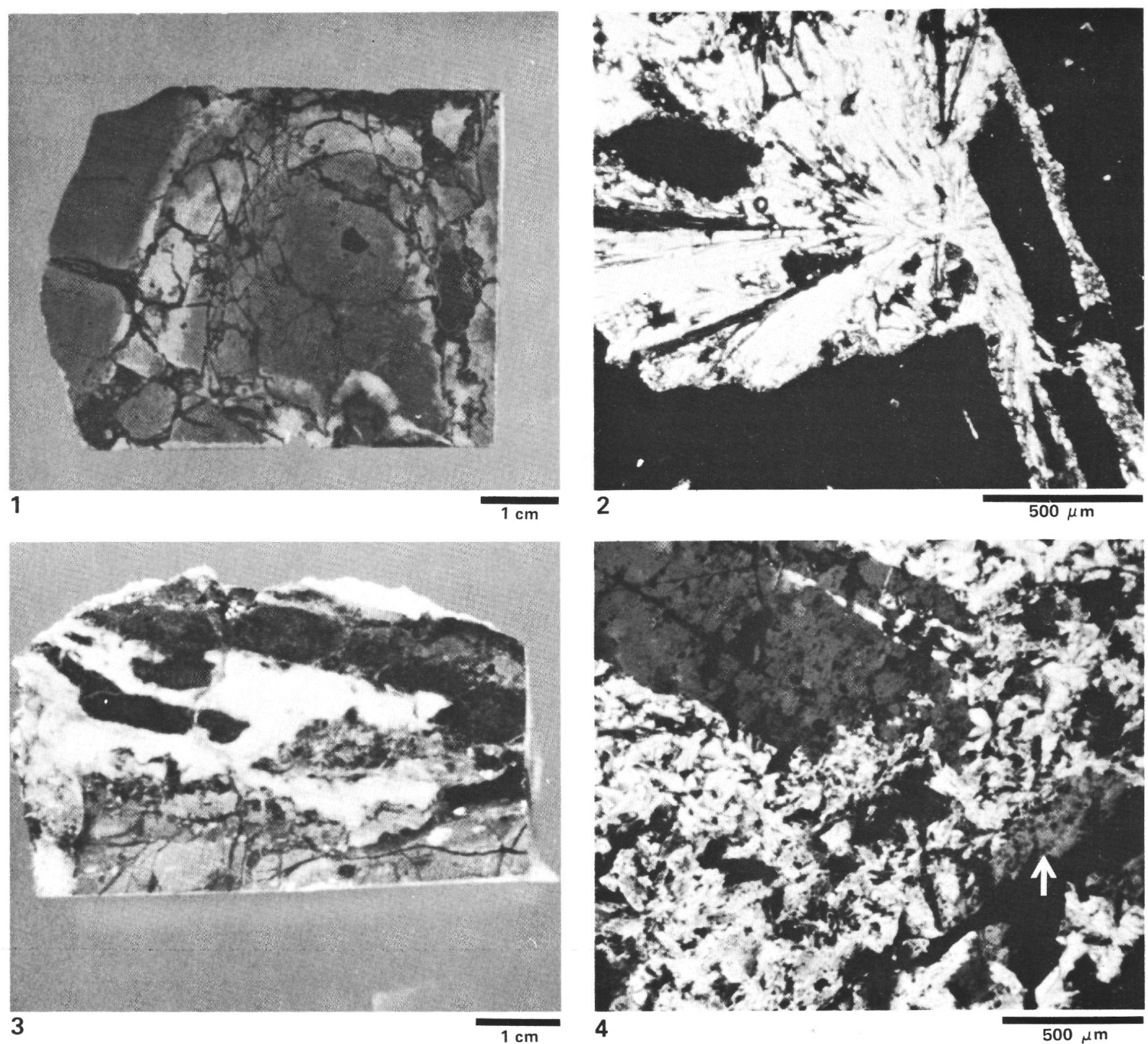

Plate 1. 1. Anhydrite (white) at center of veins along bottom and right of sample. Outer parts of large veins and networks of small veinlets consist of clay minerals (black), quartz, and pyrite. Sample 74-1, 46-49 cm. 2. Thin-section photomicrograph of anhydrite prisms at the center of vein rimmed by quartz, clay minerals, and pyrite. Host basalt appears black. Crossed polars; same sample as Fig. 1. 3. Large white vein, consisting of anhydrite, laumontite, and prehnite, with minor epidote, and rimmed by chlorite. Host basalt (gray and black fragments) is extensively replaced by albite, chlorite, actinolite, and sphene. Sample 141-1, 58-61 cm. 4. Thin-section photomicrograph showing anhydrite lath (gray) in vein partly replaced by feathery looking prehnite. Arrow at lower right of photograph indicates isolated anhydrite fragment (gray) that was originally part of the large anhydrite prism in upper left. Crossed polars; same sample as Fig. 2. 